\section{B A Institute of \\ YK Business Administration \\ 页下 \\ Karachi \\ Leadership and Ideas for Tomorrow}

\section{Business Review}

\author{
Volume 10 Issue 2
} July-December 2015

7-1-2015

\title{
Front Matter of Volume 10 Number 2
}

Tufail A. Qureshi

Institute of Business Administration, Karachi

Follow this and additional works at: https://ir.iba.edu.pk/businessreview

Part of the Business Commons

c) (i)

This work is licensed under a Creative Commons Attribution 4.0 International License.

\section{Recommended Citation}

Qureshi, T. A. (2015). Front Matter of Volume 10 Number 2. Business Review, 10(2), 1-4. Retrieved from https://doi.org/10.54784/1990-6587.1350

This article is brought to you by iRepository for open access under the Creative Commons Attribution 4.0 License and is available at https://ir.iba.edu.pk/businessreview/vol10/iss2/1. For more information, please contact irepository@iba.edu.pk. 
https://ir.iba.edu.pk/businessreview/vol10/iss2/1

DOI: https://doi.org/10.54784/1990-6587.1350

ISSN 1990-6587

Volume 10 Number 2 July - December 2015

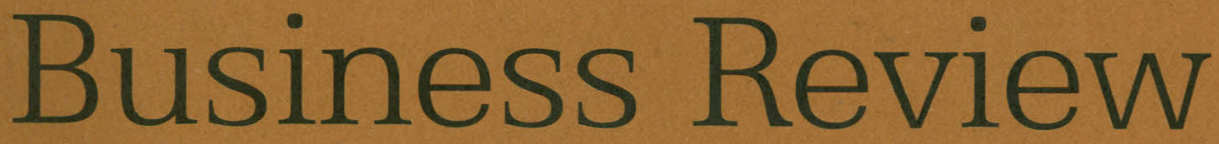

Leadership and Ideas for Tomorrow

IBA

त्रैk

RESEARCH JOURNAL

of

THE INSTITUTE OF BUSINESS ADMINISTRATION

Published by iRepository, June 2021

KARACHI-PAKISTAN 
https://ir.iba.edu.pk/businessreview/vol10/iss2/1

DOI: https://doi.org/10.54784/1990-6587.1350

IBA

IV

\title{
BUSINESS REVIEW
}

\author{
Volume 10 Number 2 \\ July - December 2015
}

\section{INTERNATIONAL EDITORIAL BOARD}

Ishrat HUSAIN

Chairman Board of Editors

Deepak KAPUR

Institute of Management Technology Ghaziabad, UP, India

Khurshid M. KIANI

Bang College of Business, Almaty Republic of Kazakhstan

S.W.S.B. DASANAYAKA

University of Moratuwa, Sri Lanka

Menno ADEN

Technische University, Dortmund Germany

Liu Jun YING

Jinanjin University, Jian Jin, China

Naved AHMED

Institute of Business Administration, Karachi, Pakistan

M. Aminul ISLAM

University Sain, Malaysia

Bettina ROBOTKA

Humbolt University, Berlin Germany

Akif HASSAN

Iqra University, Karachi-Pakistan

Khursheed OMER

University of Houston, Downtown Texas USA

Zeenat ISMAIL

Institute of Business Administration, Karachi-Pakistan

Huma BAQAI

Institute of Business Administration, Karachi, Pakistan
Tufail A. QURESHI

Editor
Arun Diwaker Nath BAJPAI

Rani Durgavati University, Jabalpur, (MP) India

Talat A. WAZARAT

Institute of Business Administration Karachi-Pakistan

Shamas-ur-Rehman TOOR

University of New South Wales, Australia

Khadija Malik BARI

Institute of Business Administration Karachi-Pakistan

Ahmed Audu MAIYAKI

Bayero University, Kano Nigeria

Agung NUGROHO

Atma Jaya Cotholic University, Jakarta, Indonesia

Faisal Manzoor ARAIN

Southern Alberta Institute of Technology Canada

Low Sui PHENG

National University of Singapore

Badar Alam IQBAL

Aligarh Muslim University Aligarh,(UP) India Abdul RASHID

Intrnational Islamic University, Islamabad-Pakistan Mirza Sardar HUSSAIN

Institute of Business Administration, Karachi-Pakistan Nadir Ali KOLACHI

Sky Line University, U.A.E

Dan QU

Hunan University, China

Business Review is a peer reviewed bi-annual research journal of the Institute of Business Administration (IBA) Karachi. It is recognized by the

Higher Education Commission (HEC) of Pakistan and is internationally abstracted/ indexed in the Journal of Economic Literature (JEL) and EBSCO database.

Published by iRepository, June 202 Business Review is a non profit Organization 


\title{
BUSINESS REVIEW
}

\author{
IBA \\ प्रैk
}

RESEARCH JOURNAL

of

THE INSTITUTE OF BUSINESS ADMINISTRATION KARACHI - PAKISTAN

Published by iRepository, June 2021 
Volume 10 Number 2

\section{IBA YरK} July - December 2015

\section{CONTENTS}

Editorial Perspective

\section{ARTICLES}

Global Dominance Potential of Chinese Corporations

Javed A. Ansari

A Curious Case of China

Sana Khalil

National Culture and Business Resilience: An Exploratory Study of Two Chinese

Construction Firms Operating in Singapore

Low Sui Pheng, Gao Shang, Teo Wee Kiat, Ken

Us Policy of Technology Transfer to China

Amna Mahmood, Sadaf Farooq

The Nexus of Financial Deepening, Economic Growth and Poverty: The case of Pakistan Abdur Rahman Aleemi, Muhammad Azam

Does ESG Investment Enhance Investment Returns

CA.Hemlata Chelawat, I.V. Trivedi

\section{CASE STUDY}

Strategic Dimensions of Organizational Productivity (A Case Study on the Proposed

HRD Directions for Modern Companies)

Nadir Ali

Supply Chain Performance Measurement for Services: An Operational level Framework Asher Ramish, Sarwar M. Azhar

Transferability of Western MNCs Human Resource Management Practices: A Case Study Mohammad Khasro Miah, Shahid Hossain

\section{COMMENTARY}

Congruence Between Interest and Field of Study as Determinant of Academic Achievement Among University Students In Gilgit-Baltistan

Sadiq Hussain, Zaighum Ali, Ansar-ud-Din

\section{LITERARY NOTE}

Sikandar In Persian Literature: Narcissistic Leadership in Childhood and Adolescence

Naheed P. Malbari

Donna Tartt: The Secret History: New York: Vintage, Paperback, 569Pp

Nadya Chishty-Mujahid 


\section{Editorial Perspective}

\section{Leadership and Ideas for Tomorrow}

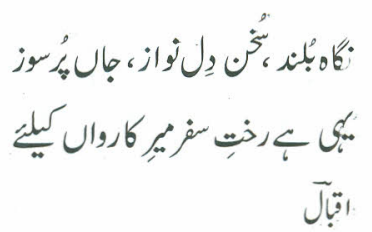

In the grand succession of phenomena and the alternation of the day and night, how silently "time present", carrying the burden of "yesterday", laden with happiness and sorrows, blends into "Tomorrow"! Time moves and ceaselessly continues on its journey. Nothing abides, except the echoes of silence; nothing is permanent, but the shadows of what used to be. "Tomorrow and tomorrow and tomorrow creeps into the petty pace from day to day".

"Though nothing can bring back the hour

Of splendor in the grass, of glory in the flower;

We will grieve not, rather find

Strength in what remains behind"

Ever since the beginning of human history, two processions have marked the unbroken onward rush of life: the procession of Ideas and the procession of Cultures. Sometimes this movement of life towards the yet to be has been quiet and uneventful, as a sleep without dreams; at other times, the lure of what might have been has been a rude awakening of human mind from the slumber of thus it is and it cannot be otherwise.

But the most poignant moments in man's life are personal when he becomes aware of himself as a conscious subject. Standing before the future realizing that life has more than one season and more than one round of day and night. Historically, neither man's transcending visions nor his idealizations have been a perfect deposit. Like life, they have always been the fleeting shadows of "becoming". Since it is not possible, therefore, we should not aim at formulating neat definitions of these movements, i.e. the movement towards ideal transfiguration of man's being-in-the-world. The best we can do is to take them as the whole of what they have been, i.e. man's need to understand himself and his Lived-World. Such understanding has amply demonstrated that so long as this need is alive, nothing is more vital and compelling in the lives of a people; but when it is dead, it is dustily dead.

Again, ever since the advent of human history, in relation to himself and the lived "reality" that surrounds him, two tendencies have simultaneously characterized man's beingin-the-world: the tendency towards necessity and the tendency towards freedom. Both these tendencies have been reflected in his world-views; sometimes in his passive and resigned acceptance of the world as it is and sometimes in his conscious and creative affirmation of the world as it ought to be. Sometimes his self-understanding and the idealizations of his world have resulted in his creative rage against the petrifying necessity which diminishes his vision and passion to be larger than his situation. This is the way and the wont of heroic leadership. But there have been times, dark and depressing, when man has acquiesced and succumbed to the lure of passive and grave acceptance of the "given" world as his fate and destiny, something pre-ordained that cannot be changed and therefore cannot be other than what it is. Such is the pathos of obedience to necessity.

The history of Leadership and Ideas is the story of the struggle between these antithetical tendencies as they have shaped man's ideas about himself and his Life-World. Historically, these tendencies have acted as two distinct cultural attitudes, representing his ways of being-in-the-world, his relationship to himself and the ways of his making the world 
his own. Ideas supply goals; they lend meaning and purpose to life and human actions. Ideas provide ideals that guide human conduct and behavior. Ideas are never fully or clearly visualized; ideals are never fully or completely realized. Ideas and ideals both represent the horizontal and perspectival unfoldment of paradigms. They reflect man's unceasing and never ending march towards his uncertain, unpredictable and constantly expanding future. As such, they tell the story of man's transcending consciousness. They, as cultural phenomenon, portray his relationship to his self-understanding, his vision of life and his notion of the LifeWorld, at a given stage of its distinctive idealizations.

Concept of the life-world is a broad and inclusive category under which are subsumed man's worlds of political, social, economic, moral, religious and corporate realities. Each one of these worlds and their thematic variations signify the worldliness of man's hyphenated relationship to his being-in-the-world. These worlds cannot be understood without incorporating human metaphor into the specific and distinctive relations which characterize these worlds. The thought here is that there is no such thing as "the world"; only the worlds exist: yours and mine, his and hers, ours and theirs, material and spiritual, moral, ethical, religious, business, corporate, progressive and retrograde etc. The world is not a geographical locality either. It is a state of mind. Phenomenologically; the "world", as a concept, represents our way of inhabiting our spatio-temporal environment and the way of our being-in-the-world. Man lives in different environments. The Lived World gives meaning and sense to his world and determines the paradigm of his world. In this sense, we do not live in different worlds. We live in the same world differently.

It is a substantive philosophical generalization that the History of Leadership and Ideas can best be understood as the history of man's cultural relationship to his world. From cultural standpoint, man's being-in-the-world is the sphere in which all categories of progressive and evolutionary thought, social development, moral and religious selfconsciousness, economic and political rebellion and revolt, scientific and technological revolutions, corporate and business orientations are setup. It is in this context that we need to finally ask the question concerning the sense and meaning, value and purpose, pertinence and relevance of the programme we need to pursue under the caption of Leadership and Ideas for Tomorrow. The reason being that man has his being in the manner of becoming, even when he lives differently in the same world i.e. his own world. Let us also not forget that the ultimate purpose of all idealizations, scientific inventions and technological developments is the humanization of man. Man's failure in this regard is his failure as a man.

In our deep sentimental and emotional attachment to Leadership and Ideas for Tomorrow, as something more than a slogan, as something that we feel will fulfill our sociocultural needs of the times to come, we feel that it is a theme which in all possible variations that can be built upon it, must be pursued wholeheartedly as a full-fledged teaching programme and as a part of our academic structure, with utmost pedagogical devotion as something more than a theoretical and intellectual filler of our teaching programme. It must be pursued intensely, disturbingly, creatively and dangerously both in its existential relevance and in relation to its experiential relevance ontogenetically, to see the difference it should make in our personal development and members of a developing community.

As a phenomenological requirement, we need to examine our ideas not only in their historical setting but also with reference to their socio cultural and existential meaning. In other words, we need to examine the significance and relevance of each idea on two levels Social and Existential. For instance, in relation to our socio-cultural existence we should ask: what difference will the acceptance or rejection of an idea make in our interpersonal relationships, community development and national awareness. On the existential level, we must examine its relevance, meaning and significance in relation to the difference it will make in our starkly irreplaceable existence and as a member of the community of self-seeking individuals, standing at the threshold of our being able to be. We need not hesitate to draw 
even those ideas which are antagonistic and antithetical to each other into the course structure of our programme to understand what it means to be when we say we know or what does it mean to exist when I say I am. Who am I when I say I exist? What does it mean to be when I say I know?

The knowledge that makes a difference in our lives rest upon the integral relationship between knowing and being. To know means to be and being without being is not being at all. If you know the meaning of honesty, then be honest. If you know the meaning of truth then it is categorically imperative for you to become truthful. Ethics and morality, existentialism and religion, leadership and political idealism demand that to be what we know we must first draw our knowledge into an attitude and a tendency. Pedagogically, in pursuit of leadership and ideas for tomorrow we should not shy away from thinking new thoughts, feeling new emotions and asking new questions simply because they have been ignored and tabooed as sanctimonious and sacrosanct. We must not sacrifice the future at the altar of yesterday. In order to inherit the future we can proudly call our present, we must dare to ask painful questions today and fear not the painful answers. Let us feel the pain and let our pain make us grow, remembering that to grow means to outgrow. Indeed, Socratic Aristocracy of the unerring wise, virtuous, and righteous is not an easily available alternative in this "best of all possible worlds". It is therefore better to know some of the answers to all the questions we can possibly ask. History of ideas teaches us that it is the mark of wisdom to remember that an unexamined life is not worthy of an honorable man who knows the answer to the question: is something good because you like it, or should you like it because it is good?

The question has often been asked, sometimes in passing, sometimes in all earnestness: what is more important: to live or to understand life? To know or to be? We must argue and defend that to live and to understand life are both equally important components of a single unified and unifying process. Together they constitute a single reality. With reference to various ideas in relation to leadership we must examine the meaning of the essential unity between knowing and being. Otherwise, we live in denial and bad faith. It is a challenging and inescapable predicament of a moral person living in an immoral society. Thoughts and more importantly, the ideas, such as these, are the stuff our life is made of.

And man? What about him, a creature so late emerged and so soon shall expire? Unless he rises above his predators, to become larger than who he is and is capable of becoming, man is a poor thing indeed. We each have a path in life, we each have a goal we are seeking. Each goal is attainable if we are on the right path and moving in the right direction. The shortest distance between where we are and the goal we are seeking, however distant, however far, is the straight path. The shortest distance between two points is the straight line. Each goal is within walking distance if we have the time and patience, perseverance and courage and the "temptation to exist". Our lust for life is contingent upon our passion to understand that life, as Robert Frost has said so piercingly, is a trial by existence. They alone live who dare to be wise (Sapere Aude), and are not afraid to know and to understand that.in life "the reward of daring is to dare still". No one lives without the temptation to exist. He who thinks about life must be willing to live the way he thinks and dare to say; cogito, ergo sum, I think therefore I am. Accordingly, he, who loves life must love truth more than life and be willing to die for it. That is the existential logic. It is an idea laden with fear and trembling. But without incorporating it into our discourse on leadership or into any other variation built upon it; how long can we refrain ourselves from becoming historical? It must be based on the ontogenetic concept of knowledge which is the existential entailment of propositional logic. Ontogenetic knowledge is a vertically integrated system of knowing and being; it is any attitudinal disposition. Remembering, always, that to know means to be. Here we have no choice and we are without excuses, unless we choose to live in denial and bad faith. 
Truth loving people cannot stray from truth for long. They who love truth cannot love the thing they love more than the truth.

We also need to focus upon the movements generated by the Ideas, not only as various ways of thinking e.g. idealism, materialism, pragmatism, existentialism, etc. but also with reference to their cultural meaning, as Ways of Living, i.e. the ways of circumstancing our environment or the lived-world, such as creative, practical, religious and moral etc. The thought here is that all social and political, moral and ethical, religious and cultural, scientific and technological revolutions, indeed every virtue and vice, prudent and wise act, every flawed and misguided attitude and behavior is founded on an idea. Such considerations reflect upon the role ideas have played in the lives of the leaders, their philosophy of life and their world view.

What then is an idea? An idea is a belief, a disposition or a tendency. However, apart from its embodiment in human thought and action, an idea is nothing and it means nothing. In itself, an idea is blind, barren and empty. Apart from human will as an attitudinal disposition, an idea means nothing, intends nothing, wills nothing and does nothing. Embodied in human consciousness, ideas have ruled the world and determined the destinies of mankind. History of ideas is a record of man's achievements and failures, glory and grandeur, hopes and moral despair, shattered dreams and un-fulfilled desires. So understood, History of Ideas teaches us that history is also a concept without percept; it is an abstract notion, blind and empty of any meaningful content and it does not exist. It creates nothing, builds nothing, destroy nothing. It does not fight wars. It does not make peace. It is a misnomer and means nothing. It is man, possessed by an idea, who makes history through his choices and decisions, creative resolves and destructive will. And that reflects equally sharply on the role of Leadership in human history.

History is a record of what man did or did not do, what he achieved or failed to accomplish, the emotions he did not feel, the ideas he only dimly visualized, the thoughts he did not think, the guilt and shame he did not feel. History originates in man's autobiographical consciousness. It succeeds when man is victorious and fails man flounders. Historical events are expression of man's idealizations and extension of his own projections, his creative urge and destructive rage. From our study of the History of Ideas we learn that human history is not only the glory of man but also his perdition. Ironically man does not learn from History, although, as Marx said history has repeated itself many times, the first time as folly and the second time as tragedy. Marx added hurriedly, and third time as a farce. We, living in Corporate Pakistan, know how true it is living in farcical times.

In teaching the programme on Leadership and Ideas for Tomorrow, we should be able to learn what is written in the idiom of many cultures of different times and climes, that whoever wishes to find the meaning of life must first examine his own meaning intending acts and whoever wishes to know whether living as such is more important than knowing the meaning of life must first examine the nature of the hyphenated relationship between himself and his ideas. Such a relationship presents a Gestaltan view of the perspectival variations and horizontal unfoldments of his being in the world and his idealizations of the conceptual structures of his worldview.

In the realm of Leadership and Ideas, it presents a never-ending story of man's notion of the worlds, the world from which he desires to escape into the world he wishes to make his own. In other words, man's being-in-the-world is determined by the way he happens to be in the world and the meaning of his world is determined by the way he makes the world his own as a creative and co-creative intentionality as a determiner of his fate and destiny.

That is the agony and the anguish of Leadership and that is its glory and grandeur.

To be continued... 